\title{
Peningkatan Aktivitas Dan Hasil Belajar Siswa Menggunakan Media Realia Pada Pembelajaran IPS
}

\author{
Edo Dwi Cahyo \\ STKIP PGRI METRO, Jl. Banjarrejo 38 B Batanghari, Lampung Timur \\ e-mail : edodwicahyo@gmail.com
}

received : 1 March 2017

accepted : 10 April 2017

published : April 2017

\begin{abstract}
The Improving Students' Activities and Learning O utcome Using Realia Media on Social Subject. The aims of this research were to improve students' activities and learning outcome on social subject using Realia media in the fourth grade of SDN 08 South Metro. The method used in this research was Classroom Action Research (CAR), which was implemented through three cycles. The datas have been collected by using observation sheet and essay test and analyzed by qualitative and quantitative data analysis. The results showed that the use of Realia media on social subject is able to increase the activity and student learning outcomes.
\end{abstract}

Keywords: learning activity, learning outcome, realia media

\begin{abstract}
Abstrak: Peningkatan Aktivitas dan Hasil Belajar Siswa Menggunakan Media Realia pada Pembelajaran IPS. Penelitian ini dilakukan guna meningkatkan aktivitas dan hasil belajar siswa pada pembelajaran IPS dengan menggunakan media realia di kelas IV SDN 08 Metro Selatan. Metode yang digunakan dalam penelitian ini adalah Penelitian Tindakan Kelas (PTK) yang dilaksanakan melalui tiga siklus. Pengumpulan data dilakukan dengan menggunakan lembar observasi dan tes essay. Teknik pengumpulan data yang digunakan adalah teknik observasi dan tes yang kemudian dianalisis menggunakan analisis data kualitatif dan kuantitatif. Hasil penelitian menunjukkan bahwa penggunaan media realia pada pembelajaran IPS kelas IV SDN 08 Metro Selatan dapat meningkatkan aktivitas dan hasil belajar siswa.
\end{abstract}

Kata kunci: aktivitas belajar, hasil belajar, media realia 


\section{PENDAHULUAN}

Banyak usaha yang dilakukan seseorang untuk bisa mendapatkan suatu pendidikan, karena dengan pendidikan tersebut maka seseorang akan dapat membina hidup yang lebih baik. Oleh karena itu Pemerintah membuat sistem pendidikan di Negara Indonesia yang tersusun dalam Undang-undang tentang Sistem Pendidikan Nasional.

Undang-undang No. 20 tahun 2003 pasal 1 ayat 2 tentang Sistem Pendidikan Nasional menjelaskan bahwa pendidikan nasional adalah pendidikan yang berdasarkan Pancasila dan Undang-undang Dasar Negara Republik Indonesia Tahun 1945 yang berakar pada nilainilai agama, kebudayaan nasional Indonesia dan tanggap terhadap tuntutan perubahan zaman. Fungsi dan tujuan pendidikan nasional itu sendiri adalah untuk mengembangkan kemampuan dan membentuk watak serta peradaban bangsa yang bermartabat dalam rangka mencerdaskan kehidupan bangsa, bertujuan untuk berkembangnya potensi peserta didik agar menjadi manusia yang beriman dan bertakwa kepada Tuhan Yang Maha Esa, berakhlak mulia, sehat, beriman, cakap, kreatif, mandiri, dan menjadi warga negara yang demokratis serta bertanggung jawab.

Guna mewujudkan tujuan dari UndangUndang No. 20 tahun 2003 tentang Sistem Pendidikan Nasional tersebut di atas, diperlukan suatu pembelajaran bagi siswa dan guru yang mengacu pada kurikulum. Adapun kurikulum yang berlaku saat ini adalah Kurikulum Tingkat Satuan Pendidikan (KTSP). Undang-undang No. 20 tahun 2003 pasal 37 ayat 1 yang mengatur tentang KTSP memuat 10 mata pelajaran yang harus diajarkan di sekolah dasar, salah satunya yaitu Ilmu Pengetahuan Sosial (IPS).

IPS adalah bidang studi yang mempelajari, menelaah, menganalisis gejala dan masalah sosial di masyarakat dengan meninjau dari berbagai aspek kehidupan atau satu perpaduan (Sardjiyo, dkk., 2009. 1.27). Tujuan dari IPS itu sendiri yaitu untuk membina siswa agar mampu mengembangkan pengertian/ pengetahuan berdasarkan data, generalisasisi serta konsep ilmu tertentu maupun yang bersifat interdisipliner/ komprehensif dari berbagai cabang ilmu sosial (The Social Science Education Frame Work For California School dalam Sapriya, dkk., 2009: 13). Pembelajaran IPS pada setiap jenjang tidaklah sama, tentunya harus disesuaikan dengan tingkat perkembangan siswa, terutama pada pembelajaran IPS di SD.

Berdasarkan hasil observasi dan wawancara dengan guru kelas IV SDN08 Metro Selatan, diperoleh data bahwa dalam pembelajaran IPS masih banyak hasil belajar siswa yang belum mencapai nilai Kriteria Ketuntasan Minimal (KKM) yang telah ditetapkan yaitu 70, terbukti dari nilai rata-rata kelas yang hanya mencapai 61,4 . Sementara itu dilihat dari ketuntasan nilai individu berdasarkan KKM, diperoleh hasil bahwa dari 30 siswa hanya 9 siswa (30\%) yang telah mencapai KKM, sedangkan 21 siswa (70\%) belum tuntas atau belum mencapai KKM. Aktivitas belajar siswa juga masih rendah terlihat dari siswa yang cenderung ribut, banyak mengobrol dan tidak menyimak materi yang disampaikan oleh guru, serta proses timbal balik antara guru dengan siswa kurang terlihat.

Rendahnya aktivitas dan hasil belajar siswa dikarenakan pola mengajar yang bersifat teacher centered (berpusat pada guru). Kemudian guru lebih sering terpaku pada buku serta penyajian materi yang bersifat naratif dan tidak memperhatikan efisiensi waktunya sehingga membuat siswa jenuh dan tidak dapat fokus terhadap pembelajaran yang sedang berlangsung. Terlebih lagi guru belum menggunakan media yang menunjang proses pembelajaran.

Permasalahan mengenai rendahnya aktivitas, guru harus bisa menciptakan suasana pembelajaran yang dapat melibatkan siswa 
secara aktif dalam proses pembelajaran. Ibrahim \& Syaodih (2003: 118) mengemukakan bahwa untuk mencapai hasil yang optimum dari proses pembelajaran, salah satu hal yang sangat disarankan adalah digunakannya pula media yang bersifat langsung dalam bentuk objek nyata atau realia. Media realia merupakan salah satu sarana guna menunjang perbaikan proses pembelajaran tersebut. Media realia adalah benda nyata yang digunakan sebagai bahan atau sumber belajar.

Pemanfaatan media realia tidak harus dihadirkan secara nyata dalam ruang kelas, melainkan dapat juga dengan cara mengajak siswa melihat langsung (observasi) benda nyata tersebut ke lokasinya (Solihatin \& Raharjo, 2007: 27). Media realia adalah semua media nyata yang ada di lingkungan alam, baik digunakan dalam keadaan hidup maupun sudah diawetkan, seperti tumbuhan, batuan, binatang, inspektrum, herbarium, air, sawah, dan sebagainya (Asra, dkk., 2007: 5.9).

Menurut Wibowo (Warsiya, 2014: 23) ada empat langkah pokok yang dapat dilakukan dalam penggunaan media realia yaitu:

1. Menyediakan benda-benda nyata yang berhubungan dengan bahan ajar (materi ajar) agar dapat dimanfaatkan dikelas dengan efisien.

2. Menggunakan benda-benda nyata tersebut dalam proses pembelajaran dikelas. Siswa mendapatkan pengalaman langsung dari benda-benda tersebut.

3. Mengajak siswa mengamati secara langsung, kemudian bersama temannya berdiskusi tentang materi yang diajarkan.

4. Setelah mengamati dan berdiskusi serta bimbingan dari guru, siswa dapat menyimpulkan materi yang telah diajarkan.

Pelaksanaan pembelajaran dengan memperhatikan langkah-langkah media realia di atas, diharapkan siswa dapat lebih aktif dalam proses pembelajaran di kelas. Dimyati
\&Mudjiono (2009: 236-238) mengemukakan bahwa aktivitas belajar dialami oleh siswa sebagai suatu proses, aktivitas belajar adalah segala kegiatan yang dilaksanakan baik secara jasmani atau rohani selama proses pembelajaran. Sardiman (2010:100) juga mengemukakan bahwa aktivitas belajar adalah aktivitas yang bersifat fisik maupun mental.

Dalam kegiatan belajar kedua aktivitas itu harus selalu berkait. Jadi, aktivitas belajar adalah suatu kegiatan siswa yang menyangkut partisipasi, minat, perhatian dan presentasi dimana dalam proses pembelajaran yang dilakukan secara aktif serta mendapat pengalaman baru. Sehingga setelah siswa mengalami kegiatan tersebut siswa lebih mudah dalam mencapai tujuan pembelajaran yang telah ditentukan.

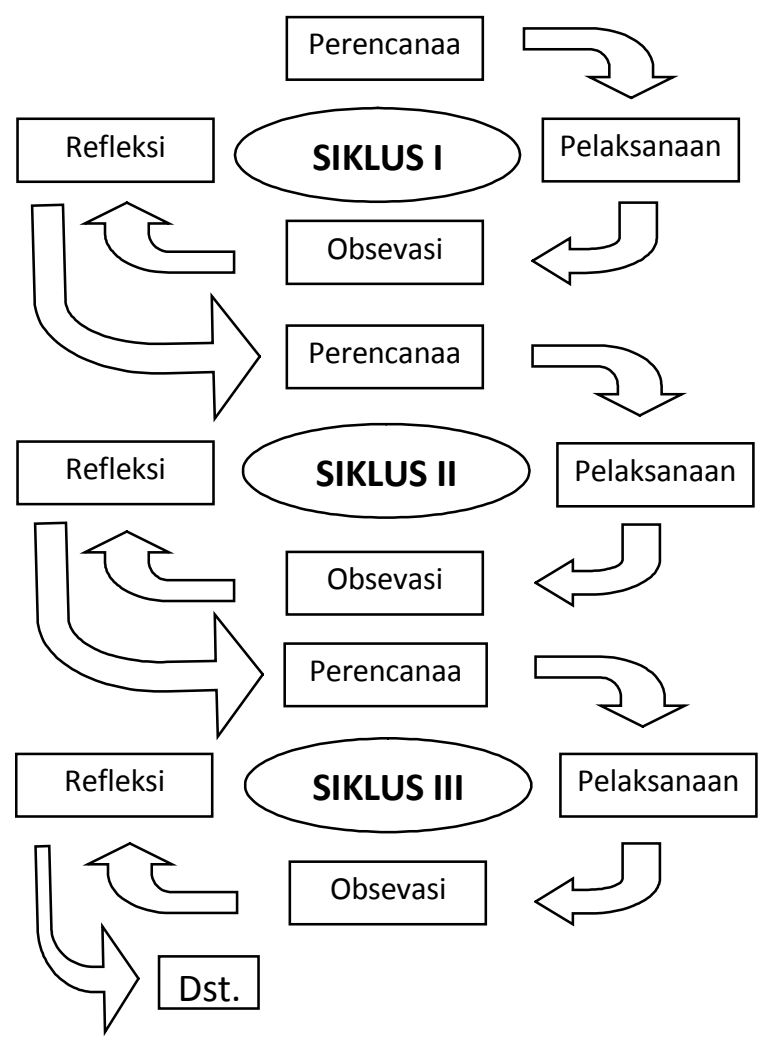

Gambar 1. Alur Siklus Penelitian Tindakan Kelas 
Sedangkan hasil belajar ialah suatu akibat dari proses belajar (Sudjana dalam Kunandar, 2010: 276). Sedangkan Soedijarto (Nashar, 2004:79) mengemukakan bahwa hasil belajar adalah tingkat penguasaan yang dicapai oleh siswa dalam mengikuti program belajar dan mengajar sesuai yang ditetapkan. Jadi, hasil belajar yaitu perubahan dalam diri siswa setelah memperoleh pengalaman belajar terutama dalam aspek pengetahuan, sikap serta keterampilan.

Tujuan dalam penelitian ini yang pertama yaitu untuk mengetahui seberapa besar peningkatan aktivitas belajar siswa pada pembelajaran IPS di kelas IV SDN 08 Metro Selatan dengan menggunakan media realia.Kedua mengetahui peningkatan hasil belajar siswa pada pembelajaran IPS di kelas IV SDN 08 Metro Selatan dengan menggunakan media realia.

\section{METODE}

Penelitian ini menggunakan metode Penelitian Tindakan Kelas (PTK) yang difokuskan pada situasi kelas yang lazim dikenal dengan Classroom Action research, Wardhani, dkk. (2007: 1.3) mengungkapkan penelitian tindakan kelas adalah penelitian yang dilakukan oleh guru di dalam kelasnya sendiri melalui refleksi diri dengan tujuan untuk memperbaiki kinerjanya sebagai guru, sehingga hasil belajar siswa menjadi meningkat. Secara garis besar terdapat empat tahapan yang lazim dilalui, yaitu (1) perencanaan, (2) pelaksanaan, (3) pengamatan, dan (4) refleksi (Arikunto, dkk., 2012: 16).

Lokasi penelitian yaitu di SDN 08 Metro Selatan, Jl. Gembira No. 47 Kelurahan Sumber Sari Bantul, Metro Selatan.Subjek penelitian adalah 1 orang guru dan siswa kelas IV SDN 08 Metro Selatan, yang terdiri dari 30 siswa dengan komposisi 16 siswa laki-laki dan 14 siswa perempuan. Penelitian menggunakan beberapa teknik pengumpulan data yaitu teknik observasi dan tes. Alat pengumpulan data yang digunakan dalam pelaksanaan penelitian tindakan kelas ini, antara lain:lembar observasi dan soal tes. Teknik analisis data yang digunakan yaitu: Analisis kualitatif(analisis kualitatif di peroleh dari aktivitas siswa dan kinerja guru selama proses pembelajaran. Analisis Kuantitatif (analisis kuantitatif diperoleh dari tes hasil belajar siswa).

\section{HASIL DAN PEMBAHASAN}

Berdasarkan hasil penelitian tindakan kelas yang telah dilaksanakan dengan menggunakan media realia pada pembelajaran IPS di kelas IV SDN 08 Metro Selatan, aktivitas dan hasil belajar siswa dapat meningkat. Hal ini dapat dibuktikan dengan adanya peningkatan aktivitas dan hasil belajar siswa pada setiap siklus penelitian tindakan kelas. Berikut deskripsi hasil penelitian tindakan kelas yang telah dilaksanakan pada siswa kelas IV SDN 08 Metro Selatan dengan menggunakan media realia

Berdasarkan tabel di atas dapat diketahui bahwa aktivitas siswa mengalami peningkatan setiap siklusnya, dari siklus I ke siklus II sebesar $11,67 \%$ dan dari siklus II ke siklus III sebesar $17,19 \%$. Hasil observasi aktivitas siswa pada siklus I pertemuan 1 diperoleh nilai persentase sebesar $51,25 \%$ dan pada siklus I pertemuan II diperoleh nilai persentase sebesar $61,25 \%$ dan terjadi peningkatan sebesar $10 \%$.

Rata-rata dari kedua hasil observasi tersebut sebesar $56,25 \%$ dan pada kriteria keberhasilan menunjukkan tingkat aktivitas siswa masih "Sedang" dalam proses pembelajaran IPS dengan menggunakan media realia.

Pada observasi aktivitas siswa siklus II pertemuan 1 diperoleh nilai persentase sebesar 65\% dan pada siklus II pertemuan II diperoleh nilai persentase sebesar $70,83 \%$ dan terjadi peningkatan sebesar 5,83\%. Rata-rata dari kedua hasil observasi tersebut sebesar $67,92 \%$ dan pada kriteria keberhasilan menunjukkan tingkat aktivitas siswa "Tinggi" dalam proses pembelajaran IPS dengan menggunakan media 
realia. Pada kegiatan observasi aktivitas siswa siklus III pertemuan I diperoleh hasil nilai persentase sebesar $81,88 \%$ dan pada siklus III pertemuan II diperoleh nilai persentase sebesar 88,33\% dan terjadi peningkatan sebesar $6,45 \%$. Rata-rata dari kedua hasil observasi tersebut sebesar $85,11 \%$ dan pada kriteria keberhasilan menunjukkan tingkat aktivitas siswa sudah "Sangat Tinggi" dalam proses pembelajaran IPS dengan menggunakan media realia walaupun belum mencapai nilai maksimal. Berdasarkan hasil rekapitulasi tersebut, menunjukkan bahwa terjadi peningkatan persentase rata-rata aktivitas siswa setiap siklusnya. Hal tersebut menunjukkan bahwa media realia berhasil meningkatkan aktivitas belajar siswa pada pembelajaran IPS.

\begin{tabular}{|c|c|c|c|c|c|c|c|c|c|}
\hline \multirow[t]{3}{*}{ No } & \multicolumn{9}{|c|}{ SIKLUS } \\
\hline & \multicolumn{3}{|c|}{ I } & \multicolumn{3}{|c|}{ II } & \multicolumn{3}{|c|}{ III } \\
\hline & $\begin{array}{c}\text { Pert. I } \\
(\%)\end{array}$ & $\begin{array}{c}\text { Pert. II } \\
(\%)\end{array}$ & $\begin{array}{c}\text { Pening- } \\
\text { katan } \\
(\%)\end{array}$ & $\begin{array}{c}\text { Pert. I } \\
(\%)\end{array}$ & $\begin{array}{c}\text { Pert. II } \\
(\%)\end{array}$ & $\begin{array}{c}\text { Pening- } \\
\text { katan } \\
(\%)\end{array}$ & $\begin{array}{c}\text { Pert. I } \\
(\%)\end{array}$ & $\begin{array}{c}\text { Pert. II } \\
(\%)\end{array}$ & $\begin{array}{c}\text { Peningkatan } \\
(\%)\end{array}$ \\
\hline 1. & 51,25 & 61,25 & 10 & 65 & 70,83 & 5,83 & 81,88 & 88,33 & 6,45 \\
\hline $\begin{array}{c}\text { Rata- } \\
\text { rata }\end{array}$ & \multicolumn{3}{|c|}{$56,25 \%$} & \multicolumn{3}{|c|}{$67,92 \%$} & \multicolumn{3}{|c|}{$85,11 \%$} \\
\hline kriteria & \multicolumn{3}{|c|}{ Sedang } & \multicolumn{3}{|c|}{ Tinggi } & \multicolumn{3}{|c|}{ Sangat Tinggi } \\
\hline \multirow{2}{*}{$\begin{array}{l}\text { Pening } \\
\text { katan }\end{array}$} & \multicolumn{5}{|c|}{ Siklus I ke Siklus II } & \multicolumn{4}{|c|}{ Siklus II ke Siklus III } \\
\hline & \multicolumn{4}{|c|}{$11,67 \%$} & \multicolumn{5}{|c|}{$17,19 \%$} \\
\hline
\end{tabular}

Tabel 2. Rekapitulasi Kinerja Guru

\begin{tabular}{|c|c|c|c|c|c|c|c|c|c|}
\hline \multirow[t]{3}{*}{ No } & \multicolumn{9}{|c|}{ SIKLUS } \\
\hline & \multicolumn{3}{|c|}{ I } & \multicolumn{3}{|c|}{ II } & \multicolumn{3}{|c|}{ III } \\
\hline & $\begin{array}{l}\text { Pert. I } \\
(\%)\end{array}$ & $\begin{array}{c}\text { Pert. II } \\
(\%)\end{array}$ & $\begin{array}{c}\text { Pening- } \\
\text { katan } \\
(\%)\end{array}$ & $\begin{array}{c}\text { Pert. I } \\
(\%)\end{array}$ & $\begin{array}{c}\text { Pert. II } \\
(\%)\end{array}$ & $\begin{array}{c}\text { Pening- } \\
\text { katan } \\
(\%)\end{array}$ & $\begin{array}{l}\text { Pert. I } \\
(\%)\end{array}$ & $\begin{array}{c}\text { Pert. II } \\
(\%)\end{array}$ & $\begin{array}{c}\text { Peningkatan } \\
(\%)\end{array}$ \\
\hline 1. & 53,14 & 58,88 & 5,74 & 68,57 & 78,29 & 9,27 & 85,14 & 88,57 & 3,43 \\
\hline $\begin{array}{c}\text { Rata- } \\
\text { rata }\end{array}$ & \multicolumn{3}{|c|}{56,01} & \multicolumn{3}{|c|}{73,43} & \multicolumn{3}{|c|}{86,86} \\
\hline kriteria & \multicolumn{3}{|c|}{ Sedang } & \multicolumn{3}{|c|}{ Tinggi } & \multicolumn{3}{|c|}{ Sangat Tinggi } \\
\hline \multirow{2}{*}{$\begin{array}{l}\text { Pening } \\
\text { katan }\end{array}$} & \multicolumn{5}{|c|}{ Siklus I ke Siklus II } & \multicolumn{4}{|c|}{ Siklus II ke Siklus III } \\
\hline & \multicolumn{4}{|c|}{17,42} & \multicolumn{5}{|c|}{13,43} \\
\hline
\end{tabular}

Berdasarkan tabel 2 di atas, dapat diketahui bahwa kinerja guru mengalami peningkatan setiap siklusnya, dari siklus I ke siklus II sebesar 17,42 dan dari siklus II ke siklus III sebesar 13,43. Kegiatan observasi kinerja guru pada siklus I pertemuan 1 diperoleh nilai sebesar 53,14 dan pada siklus I pertemuan
II diperoleh nilai sebesar 58,88 serta terjadi peningkatan sebesar 5,74. Nilai rata-rata dari kedua hasil observasi tersebut sebesar 56,01. Kriteria keberhasilan menunjukkan tingkat kinerja guru masih "Sedang" dalam proses pembelajaran IPS dengan menggunakan media realia. 
Tabel 3. Rekapitulasi Hasil Belajar Siswa

\begin{tabular}{cccc}
\hline Interval Nilai & Siklus I & Siklus II & Siklus III \\
\cline { 2 - 4 }$\leq 49$ & Frekuensi & Frekuensi & Frekuensi \\
$50-59$ & 3 & 1 & 1 \\
$60-69$ & 4 & 2 & - \\
$70-79$ & 4 & 4 & 4 \\
$80-89$ & 14 & 13 & 8 \\
$\geq 90$ & 2 & 6 & 12 \\
Jumlah & 3 & 4 & 5 \\
Nilai Rata-rata & 30 & 30 & 30 \\
Peningkatan & 68,70 & 75,03 & 81,07 \\
& Siklus I ke Siklus II & Siklus II ke Siklus III \\
\cline { 2 - 4 } & \multicolumn{2}{c}{6,33} & 6,04 \\
\hline
\end{tabular}

Pada observasi kinerja guru siklus II pertemuan 1 diperoleh nilai sebesar 68,57 dan pada siklus II pertemuan 2 diperoleh nilai sebesar 78,92 serta terjadi peningkatan sebesar 9,27. Nilai rata-rata dari kedua hasil observasi tersebut sebesar 73,43. Kriteria keberhasilan menunjukkan tingkat kinerja guru "Tinggi" dalam proses pembelajaran IPS dengan menggunakan media realia.

Pada kegiatan observasi kinerja guru siklus III pertemuan 1 diperoleh nilai sebesar 85,14 dan pada siklus III pertemuan 2 diperoleh nilai sebesar 88,57 serta terjadi peningkatan sebesar 3,43 . Nilai rata-rata dari kedua hasil observasi tersebut sebesar 86,86 . Kriteria keberhasilan menunjukkan tingkat kinerja guru sudah "Sangat Tinggi" dalam proses pembelajaran IPS dengan menggunakan media realia.
Berdasarkan tabel 3 di atas dapat diketahui bahwa hasil belajar siswa mengalami peningkatan setiap siklusnya. Pada siklus I hasil belajar siswa memperoleh nilai rata-rata sebesar 68,70, sementara itu pada siklus II hasil belajar siswa memperoleh nilai rata-rata sebesar 75,03 dan pada siklus III nilai rata-rata yang dicapai sebesar 81,07 dengan demikian terjadi peningkatan dari siklus I ke siklus II sebesar 6,33 dan dari siklus II ke siklus III sebesar 6,04. Hal tersebut membuktikan bahwa media realia berhasil meningkatkan hasil belajar siswa pada pembelajaran IPS.

Sementara itu persentase ketuntasan hasil belajar siswa setiap siklusnya dapat dilihat pada tabel 4. Berdasarkan tabel 4 dapat diketahui bahwa persentase hasil belajar siswa pada siklus I dari 30 siswa ketuntasan belajar siswa

Tabel 4. Rekapitulasi Persentase Ketuntasan Hasil Belajar Siswa

\begin{tabular}{lcccccc}
\hline & \multicolumn{6}{c}{ SIKLUS } \\
\cline { 2 - 7 } Nilai & \multicolumn{2}{c}{ I } & \multicolumn{2}{c}{ II } & \multicolumn{2}{c}{ III } \\
\cline { 2 - 7 } & $\begin{array}{c}\text { Jumlah } \\
\text { siswa }\end{array}$ & $(\%)$ & $\begin{array}{c}\text { Jumlah } \\
\text { siswa }\end{array}$ & $(\%)$ & $\begin{array}{c}\text { Jumlah } \\
\text { siswa }\end{array}$ & $(\%)$ \\
\cline { 2 - 7 }$<70$ & 11 & 36,67 & 7 & 23,33 & 5 & 16,67 \\
$\geq 70$ & 19 & 63,33 & 23 & 76,03 & 25 & 83,33 \\
\hline
\end{tabular}


menunjukkan 11 siswa $(36,67 \%)$ mendapat nilai $<70$ dan 19 siswa $(63,33 \%)$ memperoleh nilai e"70.

Pada siklus II hasil belajar siswa mengalami peningkatan dibandingkan siklus I, dari 30 siswa ketuntasan belajar siswa menunjukkan 7 siswa $(23,33 \%)$ mendapat nilai $<70$ dan 23 siswa (76,67\%) memperoleh nilai e"70.

Ketuntasan hasil belajar siswa pada siklus III menunjukkan peningkatan dari siklus I dan II dari 30 siswa ketuntasan belajar siswa menunjukkan 5 siswa $(6,67 \%)$ mendapat nilai $<70$ dan 25 siswa $(83,33 \%)$ memperoleh nilai e"70.

\section{SIMPULAN}

Berdasarkan hasil Penelitian Tindakan Kelas (PTK) yang dilakukan terhadap siswa kelas IV SDN 08 Metro Selatan pada pembelajaran Ilmu Pengetahuan Sosial (IPS) dapat disimpulkan bahwa penggunaan media realia pada pembelajaran IPS terbukti dapat meningkatkan aktivitas belajar siswa. Hal ini sesuai dengan hasil penelitian terhadap aktivitas belajar siswa yang telah dilakukan mulai dari siklus I, II dan III dan terjadi peningkatan di setiap siklusnya. Rata-rata aktivitas belajar siswa pada siklus I sebesar 56,25\% kemudian pada siklus II sebesar $67,92 \%$ dan pada siklus III sebesar $85,11 \%$, dengan demikian terjadi peningkatan dari siklus Ike

siklus II sebesar 11,67\% dan dari siklus II ke siklus III sebesar $17,19 \%$, dan penggunaan media realia pada pembelajaran IPS terbukti dapat meningkatkan hasil belajar siswa. Hal ini sesuai dengan nilai hasil belajar yang telah diperoleh siswa pada siklus I, II dan III. Pada siklus I nilai rata-rata hasil belajar siswa sebesar 68,70 , kemudian pada siklus II nilai rata-rata sebesar 75,03 dan pada siklus III sebesar 81,07, dengan demikian terjadi peningkatan dari siklus I ke siklus II sebesar 6,33 dan dari siklus II ke siklus III sebesar 6,04. Bila dilihat dari persentase ketuntasan hasil belajar siswa, dari 30 siswa pada siklus I persentase ketuntasan belajar siswa sebanyak 19 siswa $(63,33 \%)$, pada siklus II meningkat menjadi 23 siswa $(76,67 \%)$ dan pada siklus III meningkat menjadi 25 Siswa $(83,33 \%)$.

\section{DAFTAR RUJUKAN}

Arikunto, Suharsimi dkk. 2012. Penelitian Tindakan Kelas. Bumi Aksara. Jakarta.

Asra, dkk. 2007. Komputer dan Media Pembelajaran SD. Depdiknas. Jakarta. Dimyati \& Mudjiono. 2009. Belajar dan Pembelajaran.Rineka Cipta. Jakarta.

Ibrahim, R. \& S. Nana Syaodih. 2003. Perencanaan Pengajaran. Rineka Cipta. Jakarta.

Kunandar.2010. Langkah Mudah Penelitian Tindakan Kelas sebagai Pengembangan Profesi Guru. Rajawali Pers. Jakarta.

Nashar. 2004. Peranan Motivasi dan Kemampuan Awal. Delia Press. Jakarta. Sapriya, dkk. 2009. Pembelajaran dan Evaluasi Hasil Belajar IPS. UPIPRESS. Bandung.

Sardiman. 2010. Interaksi \& Motivasi Belajar Mengajar. Rajawali Pers. Jakarta.

Sardjiyo, dkk. 2009. Pendidikan IPS di SD. Universitas Terbuka. Jakarta.

Solihatin, Etin\&Raharjo. 2007. Coopeative Learning. Bumi Aksara. Jakarta.

Wardhani, IGAK dkk. 2007. Penelitian Tindakan Kelas. Universitas terbuka. Jakarta.

Warsiya, Margaretha. 2014. Peningkatan Aktivitas Dan Hasil Belajar Pembelajaran Tematik Dengan Tema Keluarga Melaluai Media Realia Siswa Kelas IaSdXaverius 3 Bandar Lampung Tahun Pelajaran 2012/2013. Bandar Lampung: Universitas Lampung. (tidak diterbitkan). 